\title{
RITUAIS FUNERÁRIOS E COMENSALIDADE NO BRONZE DO SUDOESTE DA PENÍNSULA IBÉRICA: NOVOS DADOS A PARTIR DE UMA INTERVENÇÃO ARQUEOLÓGICA NO SÍTIO DA TORRE VELHA 3 (SERPA)
}

\author{
Eduardo Manuel Batista Porfírio(1) \& Miguel António Paixão Serra ${ }^{(1)}$
}

Resumo

Abstract

\begin{abstract}
Recentes intervenções arqueológicas realizadas pela Palimpsesto - Estudo e Preservação do Património Cultural Lda. em Torre Velha 3 (Serpa), no âmbito do projecto de Minimização de Impactes decorrentes da Construção da Barragem da Laje, da responsabilidade da EDIA, resultaram na identificação de um importante conjunto funerário da Idade do Bronze. Deste universo, destaca-se um tipo de sepultura, que designámos por hipogeu, constituída por um átrio de planta maioritariamente quadrangular ou rectangular que antecede uma câmara escavada no subsolo.

O ritual funerário documentado nestes hipogeus é, em muitos aspectos, semelhante ao praticado nas cistas da Idade do Bronze do Sudoeste da Península Ibérica, nomeadamente no que se refere ao espólio ofertado e à preferência pela posição fetal para a realização das inumações. Relativamente às dádivas funerárias, verificou-se que, para além dos recipientes cerâmicos, dos elementos de adorno e dos materiais metálicos, fora depositado junto aos defuntos uma oferenda cárnea constituída maioritariamente pela extremidade da pata dianteira de bovinos.

A arquitectura e os ritos fúnebres patentes nos hipogeus de Torre Velha 3 não são propriamente inéditos na área do Bronze do Sudoeste, sendo de certo modo, prenunciados pelas características da sepultura de Belmeque. Aquando da sua descoberta no inicio dos anos 70 do século $\mathrm{XX}$, a excepcional riqueza do espólio, a singularidade da câmara sepulcral em forma de pequena gruta artificial e as características das duas inumações ai realizadas, foram sendo interpretadas como elementos exógenos que testemunhariam a existência de contactos com o "mundo" de El Argar, no Sudeste peninsular (SOARES 1994). Este carácter de unicidade, pelo menos ao nível da morfologia das sepulturas e da presença de práticas de comensalidade nos rituais funerários, tem-se vindo a alterar com a identificação de outros hipogeus da Idade do Bronze em vários locais situados nas proximidades de Belmeque, como o já referido conjunto de hipogeus de Torre Velha 3, ou Outeiro Alto 2 (VALERA E FiLIPE 2010).

Por outro lado, verifica-se que a possibilidade de contactos entre a área geográfica do Bronze do Sudoeste e a de El Argar, encontra argumentos adicionais nos contextos de Torre Velha 3 através da identificação, no espólio funerário de um hipogeu, de uma taça de pé, forma cerâmica excêntrica em relação ao reportório cerâmico tido como clássico do Bronze do Sudoeste. No entanto, escasseiam ainda os elementos que possibilitem uma caracterização da natureza destes contactos, tanto mais que os contextos actualmente conhecidos e publicados do Bronze do Sudoeste, apesar da diversidade morfológica dos contentores funerários, mantém uma forte individualidade bem patente, por exemplo, nas tipologias cerâmicas.

Pretende-se, ainda, com este trabalho, contribuir para que a comensalidade seja encarada enquanto componente fundamental do cerimonial fúnebre destas sociedades, pois cremos que, através da congregação no mesmo cenário, de vivos e mortos, estas práticas padronizadas contribuiriam para o reforço dos laços familiares. A importância do núcleo familiar aparece também plasmada noutros aspectos do registo funerário, como a deposição sucessiva ou simultânea de dois ou mais indivíduos na mesma sepultura, ou na existência de reduções associadas a inumações. O papel desempenhado pelas relações familiares seria fulcral para a manutenção do sentido de comunidade concebida enquanto entidade estruturada e materializada numa rede de povoamento dedicada à exploração dos recursos naturais da penelanície alentejana.
\end{abstract}

Palavras-chave: Rituais Funerários; Comensalidade; Idade do Bronze; Sudoeste da Península Ibérica.

\begin{abstract}
Burial Pratices and Commensality in the Southwest Iberian Peninsula Bronze Age: New Approaches From Torre Velha 3 (Serpa) Archaeological.

The construction of Laje's dam at Serpa (Beja), under EDIA's (Empresa de Desenvolvimento e Infra-estruturas do Alqueva S.A.) responsibility, started a specific program conceived to study the project's archaeological impacts, which is carried out by Palimpsesto - Estudo e Preservação do Património Cultural Lda.

During this process, several archaeological places have been studied; among them is Torre Velha 3. The fieldwork developed in Torre Velha 3 has brought to light an important Bronze Age burial assemblage dated from Iberian Southwestern Bronze Age. Each funerary structure is composed of a rectangular or quadrangular atrium connected with a subterranean chamber or hypogeum.
\end{abstract}

(1) Arqueólogos da Palimpsesto, Lda. Apartado 4078, 3031 - 901 Coimbra. Investigadores do CEAUCP-CAM. eduardoporfirio@palimpsesto.pt / miguelserra@palimpsesto.pt 
The burial rites documented in Torre Velha 3 show similarities with those of the Iberian Southwestern Bronze Age cists, namely in the flexed position choose to bury the deceased and in the offered artifacts typologies. Among the grave goods founded are ceramic and metallic objects, pendants and animal bones. The regular appearance of cattle bones, always belonging to a single leg tip, enables us to point out the practice of commensality as part of the funerary rituals.

The grave architecture and funerary rites of Torre Velha 3 hypogeums were foreshadowed by Belmeque (Vale do Vargo - Serpa) tomb, discovered during agricultural work, in the 1970's. At that time, the architectural singularity of this artificial chamber digged in the bedrock, the exceptional richness of the grave goods and the funerary ritual practiced, had been interpreted as exogenous elements from El Argar cultural area. Recent archaeological excavations in Torre Velha 3 and Belmeque neighboring areas had identified similar funerary contexts in other places like Outeiro Alto 2 (VALERA \& FILIPE 2010), giving a broader context to Belmeque's tomb.

However, the existence of contacts between the Iberian Southwestern Bronze Age and El Argar geographical areas had found additional arguments in Torre Velha 3 grave goods. Between the funerary offerings of a hypogeum had been identified a ceramic vessel whose typology resemble argaric vessels. However, in the portuguese Southwestern Bronze Age archaeological record couldn't be found additional elements to assess the nature and characteristics of that contacts with the Iberian Southeast, otherwise, there is a strong individuality in Southwestern Bronze Age ceramic typologies.

The aim of this paper is to highlight the role of commensality in the funerary rituals of these communities, because that practices contributes to reinforce and maintain the social and familiar solidarity. The family importance is clearly shaped in the burial evidence as showed by successive and simultaneous deposition of two or more individuals in the same grave, sometimes beside the rearranged remains of older burials. Familiar cohesion would be crucial to maintain strong group solidarity and consequently a structured settlement engaged in the natural resources exploitation.

Key-words: Burial practices; Commensality; Bronze Age; Iberian Peninsula Southwest.

\section{Comensalidade: Breves Considerações TEÓRICAS}

O conceito de comensalidade situa-se a meio termo entre o campo biológico e o cultural, esta particularidade é fulcral para avaliar a importância que ele desempenha na estruturação e desenvolvimento de muitos processos culturais (FERNANDES 1997; HAYDEN 1996), assumindo-se como uma temática verdadeiramente transversal, quer cultural, quer historicamente para o estudo das sociedades humanas.

Para além de uma função mais pragmática relacionada com a subsistência, o consumo de alimentos e bebidas está impregnado de elementos culturais, dos quais se destacam aqueles pertencentes ao mundo do simbólico e do normativo que condicionam aquilo que se pode - ou não - comer e beber, de que modo, em que ocasião, por quem e em que condições. A regulamentação inerente à comensalidade é, em grande medida, compartilhada pelos indivíduos de uma determinada organização social, pressupondo desde logo que participar, implica comungar de um mesmo conjunto de valores (ARANDA JIMÉNEZ 2008). Deste modo, analisar o papel que a comensalidade desempenha nos actos que pontuam a vivência de uma comunidade constitui, em grande medida, uma aproximação ao conhecimento mais aprofundado da estrutura dessa sociedade (FERNANDES 1997).

A comensalidade de feição ritual diferencia-se das actividades de âmbito semelhante realizadas quotidianamente pelos objectivos, formas de actuação e carga simbólica que configuram uma linguagem e um código próprios, actuantes no quadro de uma ocasião especial (DIETLER 2001; ARANDA JIMÉNEZ \& ESQUívEL GUERRERO 2006, 2007). No entanto, como nota Michael Dietler (2001), grande parte da eficácia comunicativa e simbólica dos rituais de comensalidade fundamenta-se precisamente na relação semiótica que estabelece com as refeições quotidianas, também elas imbuídas de alguma carga simbólica.

Os actos de comensalidade desempenham um papel importante na criação e manutenção das relações sociais, inserindo os indivíduos em redes de interacção e de solidariedade de escala diversa, desde as de carácter doméstico e local, até às de nível político regional ou mesmo extra-regional (DIETLER 2001). Deste modo, a comensalidade pode ser entendida como um dos principais domínios da acção política, constituindo um importante momento para a representação e manipulação das relações sociais (ARANDA JiMÉNEZ \& ESQUÍVEL GUERRERO 2007).

Espelhando de algum modo o largo espectro de utilização do campo teórico associado aos rituais de comensalidade, as perspectivas de estudo presentes nalguma bibliografia da temática (por exemplo: DIETLER \& HAYDEN 2001; MILNER \& MiRACLE 2002; WIESSENER \& SCHIEFENHÖVEL 1996) dão testemunho de abordagens pluridisciplinares, incluindo áreas do âmbito das ciências biológicas, económicas e sociais. No entanto, foi na área da antropologia que os estudos dedicados à compreensão dos contextos de produção e consumo ritual de alimentos mais se desenvolveram, transladando-se posteriormente para o campo da arqueologia (SÁrdA SEUMA 2010). 
Não é objectivo deste texto realizar uma abordagem aprofundada da produção teórica que envolve os conceitos de comensalidade e de práticas rituais. Pretende-se, sobretudo, destacar uma série de características que relacionam estas temáticas com a criação e manutenção do sentido de comunidade, relevantes, cremos nós, para enquadrar os contextos arqueológicos do nosso caso de estudo.

Os trabalhos de Michael Dietler têm incidido no modo como as relações políticas e sociais são negociadas e estruturadas através da comensalidade, denominando-as por "micropolíticas do quotidiano" (DiETLER 2001: 66). O modo e as funções que a comensalidade desempenha neste processo podem, segundo o mesmo autor, ser esquematizadas em três tipos: empowering feasts, patron role feast e diacritical feasts. No primeiro tipo, o objectivo relaciona-se com a obtenção e a manutenção de prestígio e capital simbólico, de modo a influenciar posteriormente as acções da comunidade através das relações interpessoais criadas no decurso das festividades e não de um cargo ou estatuto revestido de autoritarismo. No segundo caso, pretende-se legitimar e manter relações de desigualdade social através da repetição cíclica dos rituais de comensalidade. Por fim, as diacrital feasts dizem respeito ao modo como a utilização de estilos diferenciados de cozinhar e consumir alimentos e bebidas naturalizam e institucionalizam as diferenças de estatuto social (DIETLER 1996, 2001).

Partindo de pressupostos similares ao do autor norte-americano, mas colocando maior ênfase nas facetas relacionadas com a competição social, a análise de Brian Hayden destaca o papel dos rituais de comensalidade, para a instituição de toda uma série de débitos e créditos sociais a favor dos seus organizadores. A realização de rituais de comensalidade implica o investimento de uma grande quantidade de recursos alimentares, por vezes requintados e raros. Associados com outros elementos mais cenográficos como a música e a dança, acabam por se converter em riqueza e poder, contribuindo para a criação e manutenção das diferenças sociais e de sistemas políticos hierárquicos e centralizados (HAYDEN 1996, 2001).

Perante a diversidade de abordagens e perspectivas de investigação dedicadas às práticas de comensalidade evidencia-se, desde logo, a inexistência de uma definição precisa e unívoca. É no entanto possível inventariar uma série de características comuns aos vários discursos, assim, a comensalidade tem sido descrita como "... a form of public ritual activity centered around the communal consumption of food and drink" (DIETLER 2001: 67). O mesmo autor esclarece também que estas cerimónias podem caracterizar-se pela simplicidade de meios e contextos, não necessitando de um nível elevado de complexidade ao nível do cerimonial (DIETLER 2001).

Subsiste ainda a questão de identificar, no registo arqueológico pré-histórico, os vestígios materiais deste tipo de actividade ritual, especialmente para sociedades sem registo escrito e quando as representações iconográficas são muitas vezes omissas relativamente a este ponto.

Para tentar esclarecer esta problemática têm sido apontados seis indicadores que poderão testemunhar a ocorrência de rituais de comensalidade, nomeadamente: a existência de uma fonte de recursos abundante e invulnerável à sobre-exploração; comidas e bebidas difíceis de obter ou cuja produção envolva um grande investimento de trabalho e respectivos restos; recipientes de características especiais; bens de prestígio, no caso de o valor da comida e bebida ser transferido para bens não perecíveis; estruturas concebidas especialmente para os rituais de comensalidade, no caso de existirem; vestígios que testemunhem a acumulação de riqueza e poder por parte de um indivíduo ou classe dirigente (HAYDEN 1996).

Por outro lado, a investigação arqueológica dispõe tradicionalmente de toda uma vasta gama de elementos relacionáveis directa ou indirectamente com a produção e consumo de alimentos, destacando-se pela sua relevância material os materiais cerâmicos e metálicos, os contextos e estruturas que documentam situações de acumulação de restos alimentares (vegetais ou faunísticos). Também as análises arqueobotânicas, arqueozoológicas e as dos conteúdos de recipientes, assim como o estudo das paleodietas contribuem para um conhecimento mais aprofundado desta problemática (SÁNCHEZ ROMERO 2008; SÁRDA SEuma 2010).

Para o caso de El Argar, a conjugação das evidências arqueológicas e antropológicas com alguns dos indicadores propostos por Brian Hayden, têm demonstrado a existência de uma relação inequívoca entre o consumo diferenciado de várias espécies animais em rituais de comensalidade funerários e a estrutura social hierarquizada destas sociedades (ARANDA JimÉnEZ \& ESQUível GUERRERO 2006, 2007).

\section{A Comensalidade nos Ritos Funerários da Sociedade Argárica}

A Idade do Bronze do Sudeste conta com um longo historial de investigação que remonta aos finais do século XIX, quando Louis e Henri Siret, após uma série de escavações arqueológicas, publicaram em 1887, Les premiers ages du metal dans le Sud-Est de l'Espagne. O impacto gerado pela grande divulgação 
desta obra e da posterior tradução castelhana junto da comunidade científica europeia (JIMÉNEZ DIEZ 2002) transformou sítios como El Argar, Fuente Álamo e El Oficio em casos paradigmáticos para o estudo das sociedades peninsulares da Idade do Bronze.

O grande número de sítios arqueológicos intervencionados desde então na área cultural de El Argar possibilitou um conhecimento aprofundado do ritual funerário caracterizado, principalmente, pela localização das sepulturas no interior dos espaços habitacionais. Verifica-se, também, alguma diversificação ao nível dos contentores funerários, patente sobretudo na utilização de cistas, hipogeus, fossas e urnas para a realização de inumações individuais, duplas e, excepcionalmente, triplas e quádruplas. Os cadáveres eram depositados em posição fetal, acompanhados por um conjunto variado de oferendas funerárias constituídas por elementos de adorno (em pedra, osso ou metal incluindo ouro e prata), metálicos (espadas, punhais, alabardas, machados, agulhas e punções) e cerâmicos, entre os quais se destacam as características taças argáricas (ARANDA JiMÉNEZ 2008; SÁNCHEZ ROMERO et al. 2007).

Partindo da quantidade e da qualidade dos elementos materiais presentes no registo funerário, vários autores analisaram a composição da sociedade argárica, utilizando critérios unicamente tipológicos, concluindo que a variabilidade identificada ao nível do espólio confirmava a existência de uma forte hierarquização social (CÁMARA SERRANO 2001; CASTRO et al. 2001).

A utilização quase exclusiva de critérios tipológicos descurou o estudo de outras evidências presentes nos contextos funerários argáricos, nomeadamente a análise das características intrínsecas das cerâmicas e a existência de elementos faunísticos ofertados como espólio, que testemunham a realização de rituais de comensalidade aquando das exéquias. Estes cerimoniais contariam com a participação da comunidade, conforme se poderá aferir a partir das características dos contentores cerâmicos que indiciam um fabrico a pensar na exibição pública (ARANDA JIMÉNEZ \& ESQUíVEL GUERRERO 2006, 2007).

As especificidades técnicas e tipológicas de alguns dos recipientes cerâmicos incluídos nos contextos fúnebres, demonstram que a sua produção se destinaria exclusivamente à utilização no ritual funerário. As cerâmicas decoradas, especialmente as que ostentam um brilho metálico proporcionado pela decoração brunida e as taças de pé alto seriam, assim, bens de prestígio cuja forma e aparência as tornariam especialmente adequadas para o consumo de comida e bebida e para a exibição pública de riqueza e poder (ARANDA JIMÉNEZ \& ESQUíVEL GUERRERO 2006).
Um outro elemento que é necessário equacionar no âmbito desta problemática prende-se com os restos faunísticos presentes em sepulturas de várias necrópoles do mundo argárico revelando a existência de um ritual estandardizado. Ao nível das espécies escolhidas verifica-se a predominância esmagadora de bovinos e ovicaprinos, em muito menor número aparecem outros animais domésticos e selvagens, como o cavalo e o veado. Verifica-se através dos restos ósseos em conexão documentados no registo funerário uma normalização no que toca à selecção dos elementos anatómicos, constituídos maioritariamente pelas extremidades distais das patas dos animais. A selecção de animais juvenis parece demonstrar uma tendência que privilegia o consumo de carne num momento em que esta apresenta as melhores qualidades (ARANDA JIMÉNEZ \& ESQUíVEL GUERRERO 2006).

Os restos de bovino aparecem maioritariamente associados às inumações de indivíduos adultos, acompanhados dos espólios mais sumptuosos, provavelmente membros das classes dirigentes dos vários povoados. As oferendas de ovicaprinos estão presentes em sepulturas de adultos e crianças caracterizadas pela variação de riqueza dos espólios. Este conjunto de evidências aponta claramente no sentido da utilização diferencial das espécies em função da categoria social do inumado, materializada também na selecção de um só indivíduo e de uma só espécie por sepultura (ARANDA JIMÉNEZ \& ESQUíVEL GUERRERO 2007).

Os rituais de comensalidade, participados por toda ou por grande parte da comunidade, seriam um cenário indicado para o grupo dirigente demonstrar a sua riqueza e poder, através da manipulação de recipientes cerâmicos de excepção e do consumo de bebidas inebriantes e de espécies animais, como o gado bovino, com alto valor económico e simbólico. Os restantes grupos sociais, numa estratégia de emulação, organizariam as suas cerimónias de acordo com a sua posição na sociedade e consequente disponibilidade económica (ARANDA JIMÉNEZ \& ESQUÍVEL GUERRERO 2006, 2007). No decurso destes cerimoniais em que o consumo de comida e bebida ultrapassa uma dimensão puramente biológica, assistir-se-ia à criação de novos significados na esfera social e política que contribuiriam para criar, manter ou subverter as relações de poder, de género e de idade no seio da própria comunidade (ARANDA JiMÉNEZ \& ESQUívEL GUERRERO 2006).

Deste modo, o ritual funerário, encarado na sua totalidade, enquanto cenário de exibição, manipulação e amortização de riqueza económica e simbólica, era uma componente fundamental para a materialização e justificação da diferença social existente no seio das comunidades argáricas. 


\section{A Comensalidade no Mundo da Morte DO BRONZE Do Sudoeste}

A sistematização da Idade do Bronze do Sudoeste da Península Ibérica, nomeadamente no que respeita aos seus períodos inicial e médio, foi realizada por Hermanfrid Schubart em meados dos anos 70, a partir do estudo de materiais provenientes na sua maioria de necrópoles alentejanas e algarvias (SCHUBART 1975).

A designação então adoptada, "Cultura da Idade do Bronze do Sudoeste da Península Ibérica", deixa de certo modo, antever os pressupostos essencialmente tipológicos que estiveram na base desta periodização; baseada numa análise comparativa dos objectos provenientes das várias necrópoles, valorizando a presença ou a ausência de determinados tipos em conjunto com as características arquitectónicas das sepulturas e do ritual funerário (PARREIRA 1995).

Segundo Schubart, o Bronze do Sudoeste teria evoluído a partir do "Horizonte de Ferradeira", sendo portanto, contemporâneo das últimas manifestações do fenómeno Campaniforme. A designação deriva da sepultura homónima, localizada nas proximidades de Faro. Esta e outras sepulturas deste período caracterizar-se-iam ao nível do ritual funerário, pelos enterramentos individuais com o corpo estendido. Ao nível da cultura material, os tipos individualizadores do "Horizonte de Ferradeira" seriam as pontas de tipo "Palmela", os punhais de lingueta, braçais de arqueiro e botões de osso com perfuração em "V". As formas cerâmicas, apesar de derivadas dos tipos campaniformes, não apresentavam qualquer motivo decorativo (SCHUBART 1971).

Por contraste com a realidade de Ferradeira, as cistas do Bronze do Sudoeste I, apresentam dimensões mais reduzidas, sendo os cadáveres depositados na posição fetal em decúbito lateral. O espólio funerário sofre também alterações em relação ao período precedente, predominando agora punhais de rebite, pontas de seta de pedúnculo comprido, anéis em espiral, machados planos, alabardas de tipo "Montejícar" e braçais de arqueiro de dimensões menores. Os recipientes cerâmicos, por seu turno, apresentam na sua maioria um perfil carenado de paredes pouco côncavas, distinguindo-se nas suas superfícies um típico "brilho metálico", conseguido através de um brunido ou polimento intenso (SCHUBART 1971a; 1975).

As cistas do Bronze do Sudoeste II contam entre o seu espólio um conjunto cerâmico mais variado, apesar de se manterem algumas das formas cerâmicas do período anterior como as taças de tipo "Atalaia". As formas carenadas revelam carenas mais pronunciadas e algumas, como as designadas "taças tipo Santa Vitória" decoradas internamente junto ao fun- do; surgem novos tipos como as garrafas decoradas com sulcos e os recipientes de colo estrangulado, alguns com a decoração organizada em zonas horizontais, outros ornamentados com nervuras verticais. No espólio metálico continuam a marcar presença os punhais de remates e os machados planos, alguns dos quais com apêndices cónicos e de menores dimensões que os do Bronze do Sudoeste I (SchubarT 1971a; 1975).

$\mathrm{O}$ pequeno número de elementos metálicos presente nas cistas deste período contrasta com o imenso rol de objectos, maioritariamente metálicos, representados em relevo nas estelas insculturadas.

Assim, encontramos nas denominadas "estelas alentejanas" do Bronze Médio objectos como, por exemplo, espadas, machados, alabardas, goivas, associados a outros motivos como as sandálias, arcos ou um enigmático elemento ancoriforme.

Durante o Bronze Final surge outro tipo de estelas conhecido por "estelas do sudoeste", "estremenhas" ou de "guerreiro", onde se pode observar uma vasta panóplia de objectos metálicos como espadas, lanças, navalhas de barbear, pinças, fíbulas e espelhos, por vezes associados a motivos antropo e zoomórficos e a representações de escudos com escotadura em V.

A fraca representatividade no registo arqueológico dos elementos gravados nas estelas foi alvo de muitas mas nunca suficientemente esclarecedoras interpretações (GOMES \& MONTEIRO 1976/77; GOMES \& MONTEIRO 1977).

A periodização proposta por Schubart foi alvo de várias críticas relacionadas principalmente com os limites cronológicos do período I e II da Idade do Bronze do Sudoeste e, sobretudo, com o papel de fóssil director desempenhado pelas estelas, cuja cronologia deverá ser mais antiga do que aquela proposta pelo autor alemão (ALMAGRO GORBEA 1977; Ruiz-GÁlvez Priego 1984; BARCElo 1991; SOARES 1994).

A problemática relativa à periodização da Idade do Bronze do Sudoeste está longe de concluída, necessitando urgentemente de uma discussão aprofundada, o que por razões de oportunidade e de espaço não poderá ser concretizado neste trabalho que tem na temática da comensalidade o seu objectivo principal.

Os vestígios que apontam para a realização de práticas de comensalidade no decurso dos rituais funerários da Idade do Bronze do Sudoeste não são especialmente abundantes no território actualmente português. Refira-se, a título de exemplo, a necrópole da Vinha do Casão (Vilamoura), onde os responsáveis pelos trabalhos arqueológicos consideraram que as várias lareiras identificadas no espaço da necrópole teriam uma utilização de cariz ritual, dada a reduzi- 
da quantidade de restos alimentares recolhidos. No mesmo sentido consideraram a associação, na mesma sepultura, de dois recipientes cerâmicos com características morfo-técnicas distintas: uma forma aberta, normalmente uma taça carenada, seria destinada a alimentos sólidos e um vaso de maiores dimensões, por vezes com o colo alto e estreito, seria apropriado para conter líquidos (GOMES et al. 1986).

No entanto, o caso que mais se assemelha aos contextos identificados em Torre Velha 3, quer ao nível do ritual funerário, quer da morfologia arquitectónica da estrutura sepulcral, é o de Belmeque. A sepultura da Herdade de Belmeque (Vale de Vargo - Serpa) encontrada casualmente durante a realização de trabalhos agrícolas, foi publicada por H. Schubart $(1972,1975)$ e, posteriormente, reavaliada por António Monge Soares no âmbito de um trabalho de síntese sobre as necrópoles da Idade do Bronze do Sudoeste da margem esquerda do Guadiana (Soares 1994).

Segundo as informações colhidas junto dos seus achadores, tratava-se de uma gruta artificial ou hipogeu de planta rectangular, escavada nos calcários brandos da região. As dimensões então registadas apontavam para um diâmetro de 2 x 1,95 e uma altura de cerca de 1 metro (SCHUBART 1972). Da câmara partia em direcção a Noroeste um pequeno corredor, cuja entrada foi selada por uma laje de xisto colocada em cutelo. No interior da câmara, sobre uma pequena elevação, foram depositados dois indivíduos adultos, um dos quais do sexo masculino (SCHUBART 1972: 69). A inexistência de ossos do crânio no conjunto osteológico recolhido permitiu levantar a hipótese de que os dois indivíduos teriam sido decapitados em algum momento do cerimonial funerário (Soares 1994).

A existência de rituais fúnebres que demonstram um tratamento preferencial do crânio está confirmada, desde há muito, em vários contextos sepulcrais da área portuguesa do Bronze do Sudoeste, nomeadamente nas necrópoles de Alcaria do Pocinho e Curral da Pedra em Castro Marim (VeIga 2005; AMO Y DE LA Hera 1993; SchubART 1975), na cista n. ${ }^{\circ} 19$ da necrópole de Alcaria, Monchique (FORMOSINHO et al. 1953-54; AMO Y DE LA HERA 1993), na necrópole da Quitéria, Sines (SILVA \& SOARES 1981), ou, mais recentemente, no sítio Horta do Albardão 3, Évora, (SOARES et al. 2009).

Para além da arquitectura funerária e da documentação de um ritual de decapitação, o que tornou conhecida a sepultura de Belmeque, foi a excepcional riqueza do espólio que acompanhava os enterramentos. Este era composto por uma faca em bronze com rebites em electrum, dois punhais com rebites de prata, pelo menos nove aplicações em prata com a forma de tachas, para além de um vaso de cerâmica de uma forma também inédita nos contextos do Bronze do Sudoeste (SoARES 1994).

No interior da sepultura recolheram-se ainda vários ossos de bovino, nomeadamente, dois rádios e dois cúbitos esquerdos de boi doméstico (SOARES 1994). As características dos restos faunísticos, associadas ao carácter excepcional do vaso cerâmico, que poderá ter sido concebido propositadamente para dádiva funerária, apontam para a celebração de um ritual de comensalidade (SOAREs et al. 2009).

O carácter excepcional da sepultura e do espólio de Belmeque, sem paralelo naquilo que até há bem pouco era conhecido para a área do Bronze do Sudoeste, levou alguns autores que se dedicaram ao seu estudo a procurar paralelos no território de El Argar (SOARES 1994) ou mesmo mais a este, na área do Egeu (Schubart 1975; Mederos MARTín 2009). No entanto, a existência de vestígios de um ritual de comensalidade, a própria arquitectura da sepultura e vários aspectos dos elementos metálicos permitem sustentar, com alguma credibilidade, a existência de relações com territórios do sudeste peninsular. A decapitação dos indivíduos inumados ecoaria rituais de índole semelhante praticados nesta área geográfica, como o demonstra a sepultura n. ${ }^{\circ} 19$ de Castellón Alto (CONTRERAS et al. 1997).

Num passado ainda bem recente, quando o Bronze do Sudoeste era caracterizado exclusivamente pelos enterramentos em cista, o paralelo arquitectónico para Belmeque era a sepultura n. ${ }^{\circ} 95$ de Fuente Álamo (SoARES 1994). Actualmente, a existência de hipogeus com enterramentos da Idade do Bronze está bem atestada no concelho de Serpa, por exemplo no sítio Torre Velha 3 (ALVES et al. 2010) e Outeiro Alto 2 (VALERA \& Filipe 2010). Estes contextos revelaram igualmente a presença de restos faunísticos associados aos enterramentos. No caso de Torre Velha 3 documentou-se no espólio de um hipogeu uma taça de pé, de características tipicamente argáricas e sem paralelo entre os conjuntos cerâmicos da Idade do Bronze da região, constituindo-se como um argumento adicional a favor da existência de contactos com o Bronze do Sudeste.

\section{Torre Velha 3. Arquitecturas e Práticas Funerárias}

O sítio arqueológico designado por Torre Velha 3 situa-se na Herdade da Torre Velha, freguesia de São Salvador, concelho de Serpa, distrito de Beja, nas seguintes coordenadas geográficas: $37^{\circ} 58^{\prime} 14^{\prime \prime} \mathrm{N}$ e 7०31'09' W, da folha n. ${ }^{\circ} 523$ da Carta Militar de Portugal (Figs. 1 e 2). 


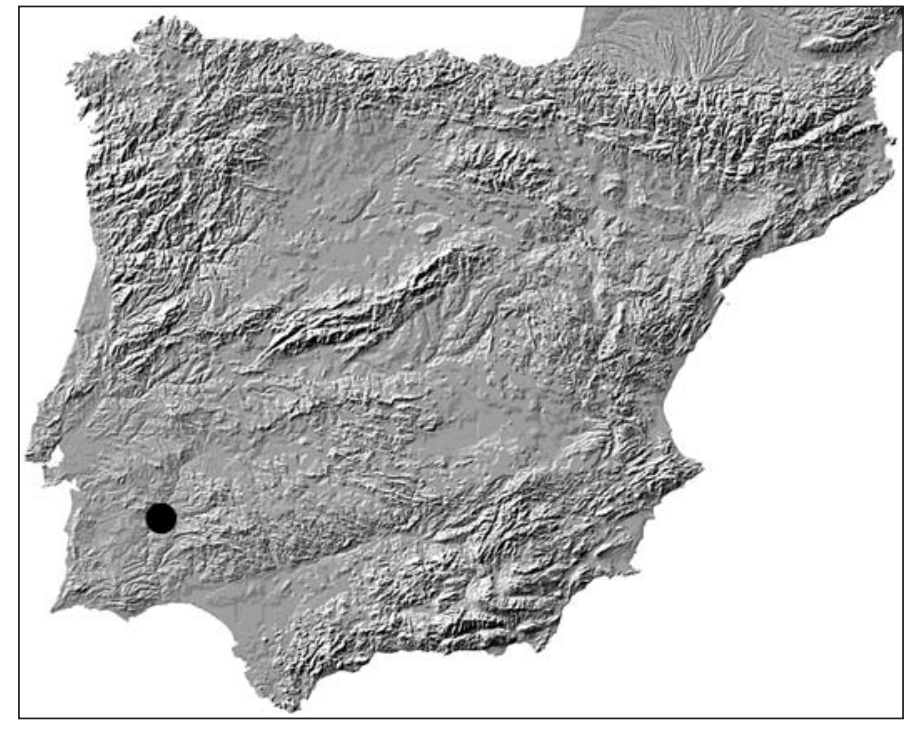

Fig. 1. Localização do sítio Torre Velha 3 na Península Ibérica.

Fig. 1. Location of Torre Velha 3 in the Iberian Peninsula.

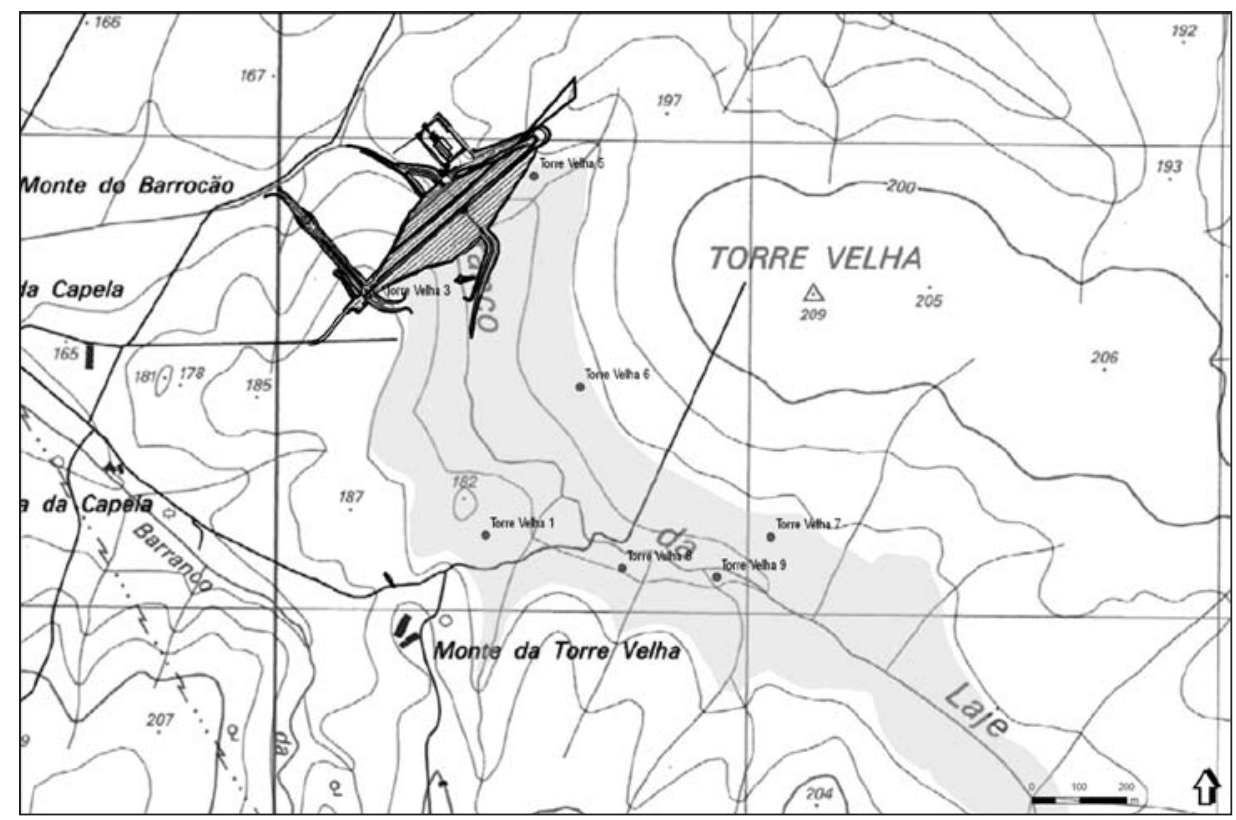

Fig. 2. Localização do sítio Torre Velha 3 na Carta Militar de Portugal, na folha n. ${ }^{\circ} 523$, esc. 1:25 000 .

Fig. 2. Location of Torre Velha 3 in the portuguese military map (1:25 000), sheet n. ${ }^{\circ} 523$.

Implanta-se numa elevação, sem quaisquer condições naturais de defesa, cuja cota máxima é de 180.70 metros. As encostas apresentam uma pendente suave, ligeiramente mais acentuada nos quadrantes Norte e Oeste. O leito da Ribeira da Laje, afluente da Ribeira do Enxoé, ladeia a elevação a Norte e a Este (Figs. 2 e 3 ).

A orografia da área de estudo é constituída por pequenas colinas de altitude pouco acentuada, com cotas que variam entre os 200 e os 230 metros. Este relevo ondulado, apesar do acentuado contraste com as grandes áreas aplanadas em redor da cidade de Beja, integra-se igualmente na peneplanície alentejana. Como é comummente referido, esta é a unidade fundamental do relevo do Alentejo, dela resultando através de processos erosivos e de deslocação tectónica a esmagadora maioria dos elementos morfológicos da região (FEIO 1952; OLIVEIRA et al. 1992).

Em termos geológicos, a Herdade da Torre Velha situa-se no maciço de Beja, mais concretamente na unidade dos "Pórfiros de Baleizão", unidade (sub)vulcânica ácida, pós-metamórfica, caracterizada pela tonalidade avermelhada dos afloramentos (OLIVEIRA et al. 1992). O local onde foi realizada a escavação arqueológica caracteriza-se pela existência de granitos desagregados do paleozóico, essencialmente filões concentrados à cota mais elevada da orografia, predominando os carbonatos, cobertos por argilas de aluvião. 


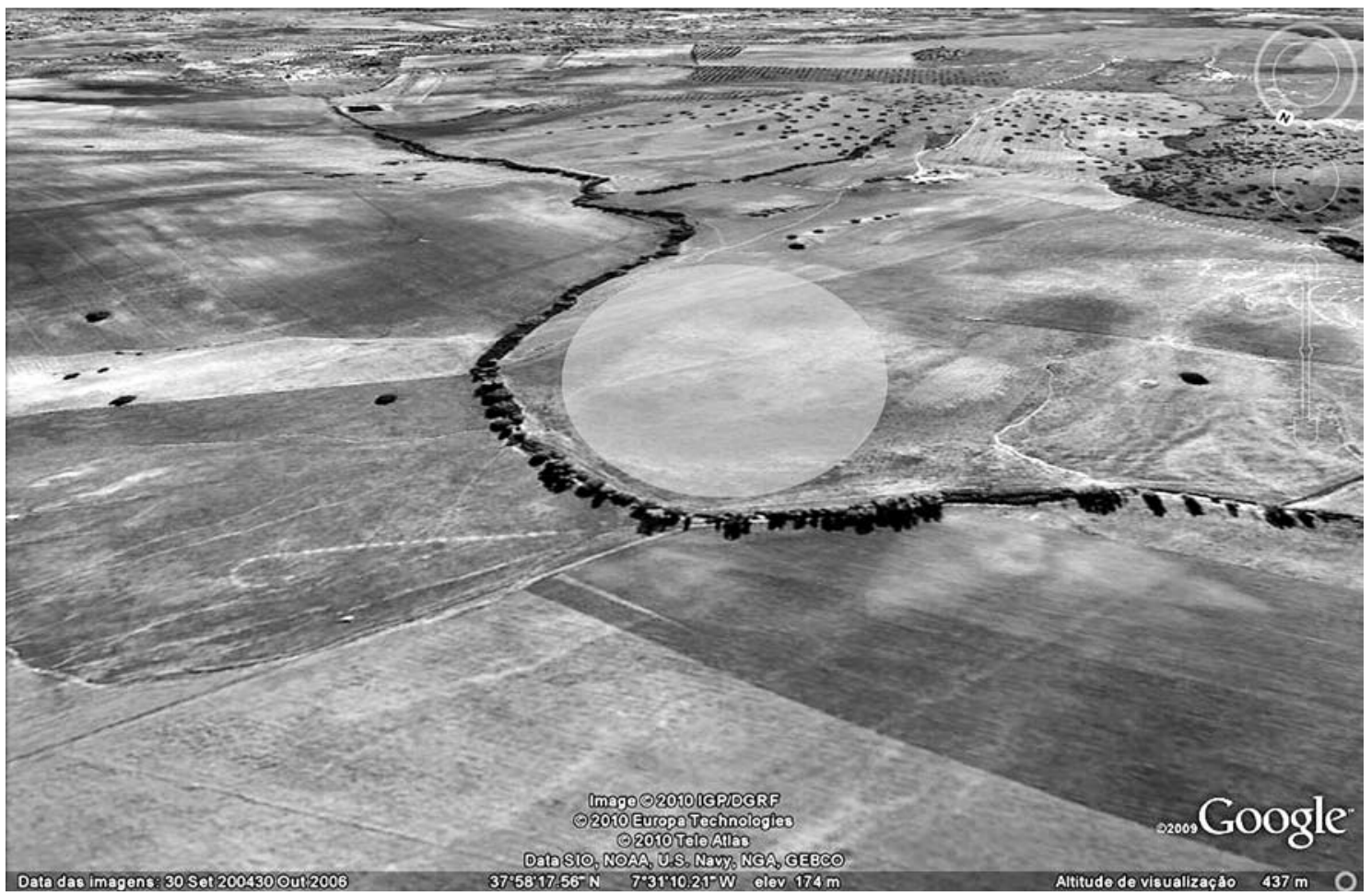

Fig. 3. Implantação topográfica do sítio Torre Velha 3 no vale da ribeira da Laje, visto de Sudeste.

Fig. 3. Location of Torre Velha 3 in Laje's stream valley. View from Southeast.

Os trabalhos arqueológicos foram realizados por uma equipa da empresa Palimpsesto Lda. no âmbito do projecto de Minimização de Impactes sobre o Património Cultural decorrentes da Construção da Barragem da Laje (Serpa), integrado no Projecto de Alqueva, da responsabilidade da EDIA - Empresa de Desenvolvimento e Infra-estruturas de Alqueva S.A. O projecto de minimização constou de uma primeira fase de sondagens arqueológicas de avaliação, a que se seguiu uma intervenção em 13996 m²$^{2}$, correspondente à totalidade da área afectada directamente pela infra-estrutura da barragem (ALVES et al. no prelo a).

No decurso desta intervenção arqueológica, foram identificadas 589 estruturas, constituídas na sua grande maioria por interfaces escavadas no "caliço" brando da região, documentando uma sequência ocupacional que se inicia no período Calcolítico com reocupações na Idade do Bronze, na I Idade do Ferro e na Antiguidade Tardia (Fig. 4). O estado preliminar do estudo destas realidades impossibilita, de momento, a atribuição de cronologias mais precisas, assim como a aferição de continuidades ou descontinuidades na longa diacronia de ocupação.

Por seu turno, a intensidade da actividade agrícola praticada nesta zona desde há séculos, conjugada com a espessura reduzida dos solos, provocou a destruição quase total dos vestígios arqueológicos de cota positiva. Esta circunstância impossibilitou a análise da estratigrafia horizontal, imprescindível para estabelecer relações entre os vários contextos arqueológicos.

A ocupação da Idade do Bronze é constituída por um conjunto de 110 estruturas arqueológicas, das quais se destacam, pela sua utilização funerária, 25 hipogeus e 11 silos/fossas (Fig 4). A estratigrafia documentada nos restantes contextos, é constituída essencialmente por depósitos onde escasseiam os materiais arqueológicos e abundam os blocos de pedra, não testemunha directamente uma utilização enquanto espaços de armazenamento de géneros alimentares, documentando apenas o abandono funcional destas realidades (ALVES et al. no prelo a, b).

A realização de enterramentos humanos em estruturas de tipo silo/fossa, morfológica e estratigraficamente semelhantes àquelas que não tiveram utilização funerária, poderá indiciar a inexistência de uma delimitação espacial entre o mundo dos vivos e o dos mortos, argumentando em favor da coexistência no mesmo espaço destes dois âmbitos da existência humana. No mesmo sentido pode entender-se o facto da análise à localização espacial dos silos/fossa com função sepulcral demonstrar uma distribuição aleatória deste tipo de estrutura ao longo da área intervencionada.

A proximidade imediata ou a justaposição es- 


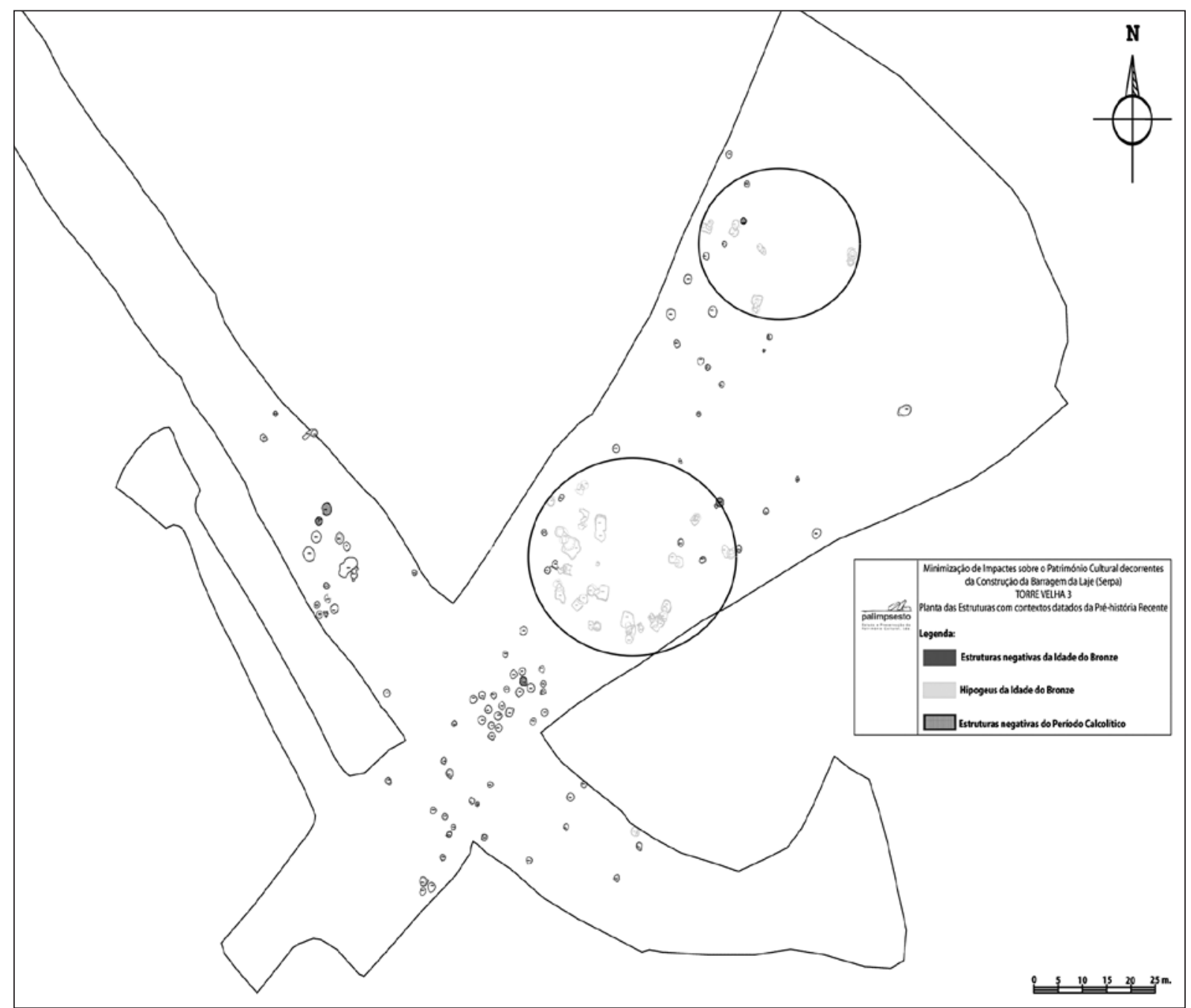

Fig. 4. Localização das estruturas arqueológicas da Idade do Bronze identificadas em Torre Velha 3. Os círculos correspondem às áreas de concentração de hipogeus.

Fig. 4. Spatial distribution of Torre Velha 3's Bronze Age context's. The circles identify the two areas where hypogea are concentrated.

pacial entre as áreas habitacionais e de necrópole verifica-se em vários períodos históricos, ocupando por vezes um papel determinante na caracterização de várias culturas, sendo o caso de El Argar o exemplo mais evidente. Para a área geográfica tradicionalmente associada ao "Bronze do Sudoeste" esta situação também não é propriamente inédita, como se verifica na zona de Sines, onde os trabalhos de Carlos Tavares da Silva e Joaquina Soares nos sítios da Quitéria e do Pessegueiro, possibilitaram localizar os respectivos povoados a poucos metros das necrópoles (SILVA \& SOARES 1981).

Sem pretensão de exaustividade na recolha das ocorrências, podem ainda citar-se os casos de Chichina (Sevilha), Castañuelo (Huelva), e de Las Minitas (Almendralejo), este último caso deverá ser tido em conta com algumas reservas, devido à reduzida área intervencionada (SOARES \& SILVA 1995, 1998;
PAVÓn SOldeVilla 2008). Na zona de Ourique, H. Schubart (citado em PARREIRA 1995) refere a existência de estruturas habitacionais junto ao monumento funerário da Alcaria, utilizado no período do Bronze Médio.

No sítio Torre Velha 3, as estruturas concebidas propositadamente para uso funerário, à excepção de um único exemplo de um nicho escavado na parede de uma fossa/silo, são constituídas por 25 sepulturas subterrâneas, que designámos por hipogeu (Figs. 5, 6 e 7).

A construção deste tipo de sepulcro iniciar-se-ia com a delimitação de uma antecâmara de planta maioritariamente quadrangular ou rectangular, numa destas paredes era escavada a câmara funerária, de planta ovalada, base aplanada e paredes côncavas, sob a forma de pequena gruta ou cavidade artificial. A comunicação entre a câmara e a antecâma- 


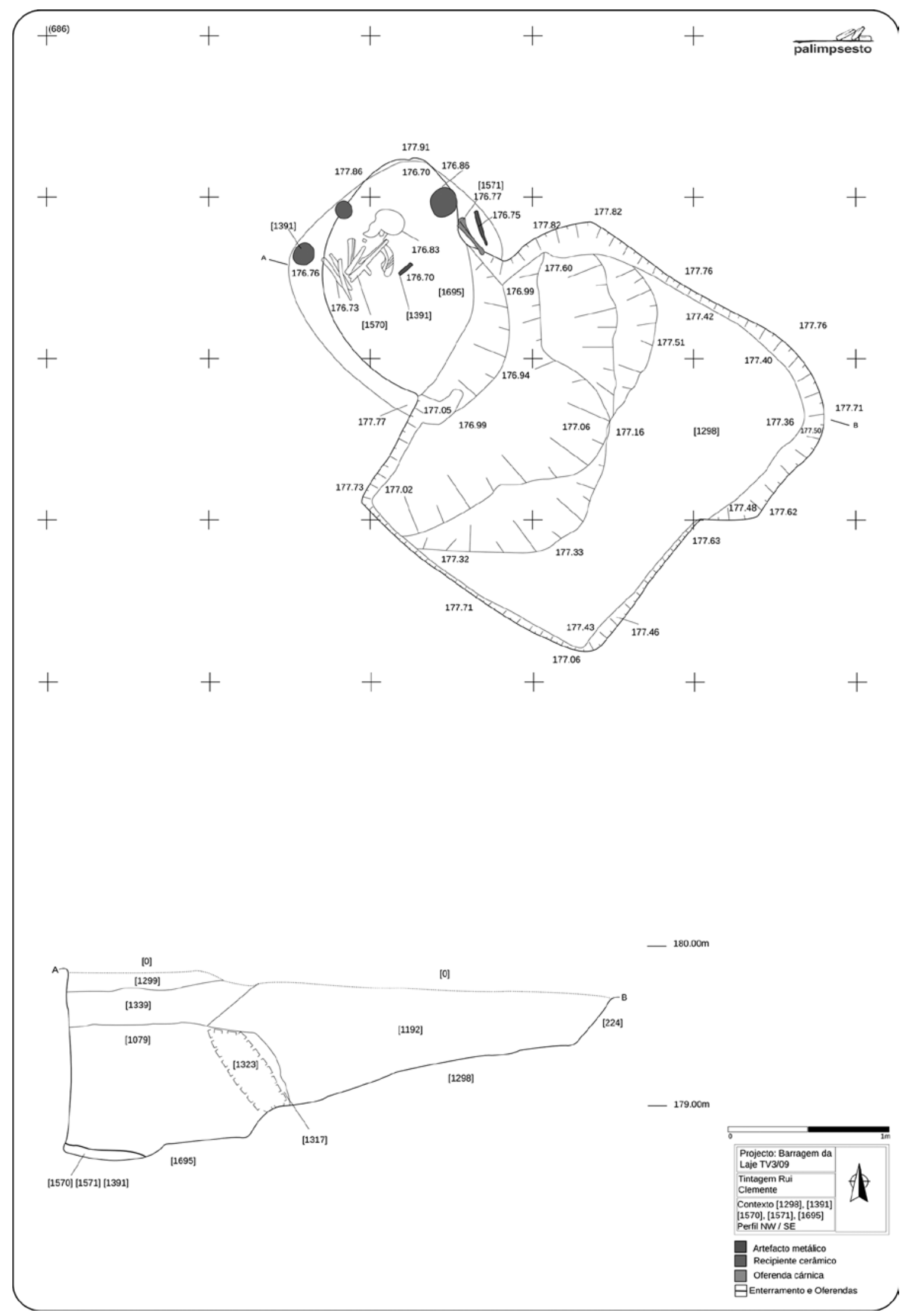

Fig. 5. Planta e perfil do hipogeu [1284-1415].

Fig. 5. Partial view of Bronze Age contexts at Torre Velha 3 after excavation. 
Rituais funerários e comensalidade no Bronze do Sudoeste da Península Ibérica: novos dados a partir de uma intervenção arqueológica no sitio da Torre Velha 3 (Serpa)

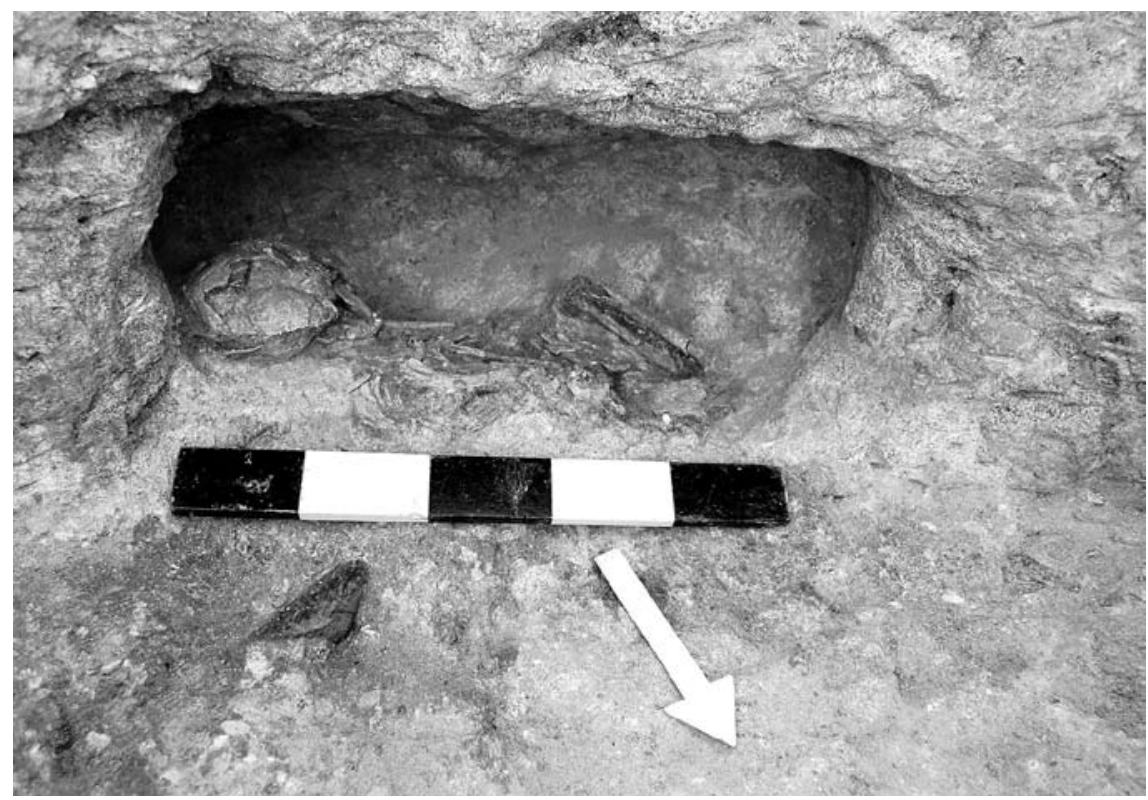

Fig. 6. Enterramento [980] em nicho escavado na parede de uma fossa.

Fig. 6. Burial [980]. A children was buried in a niche dug in a pit's wall.

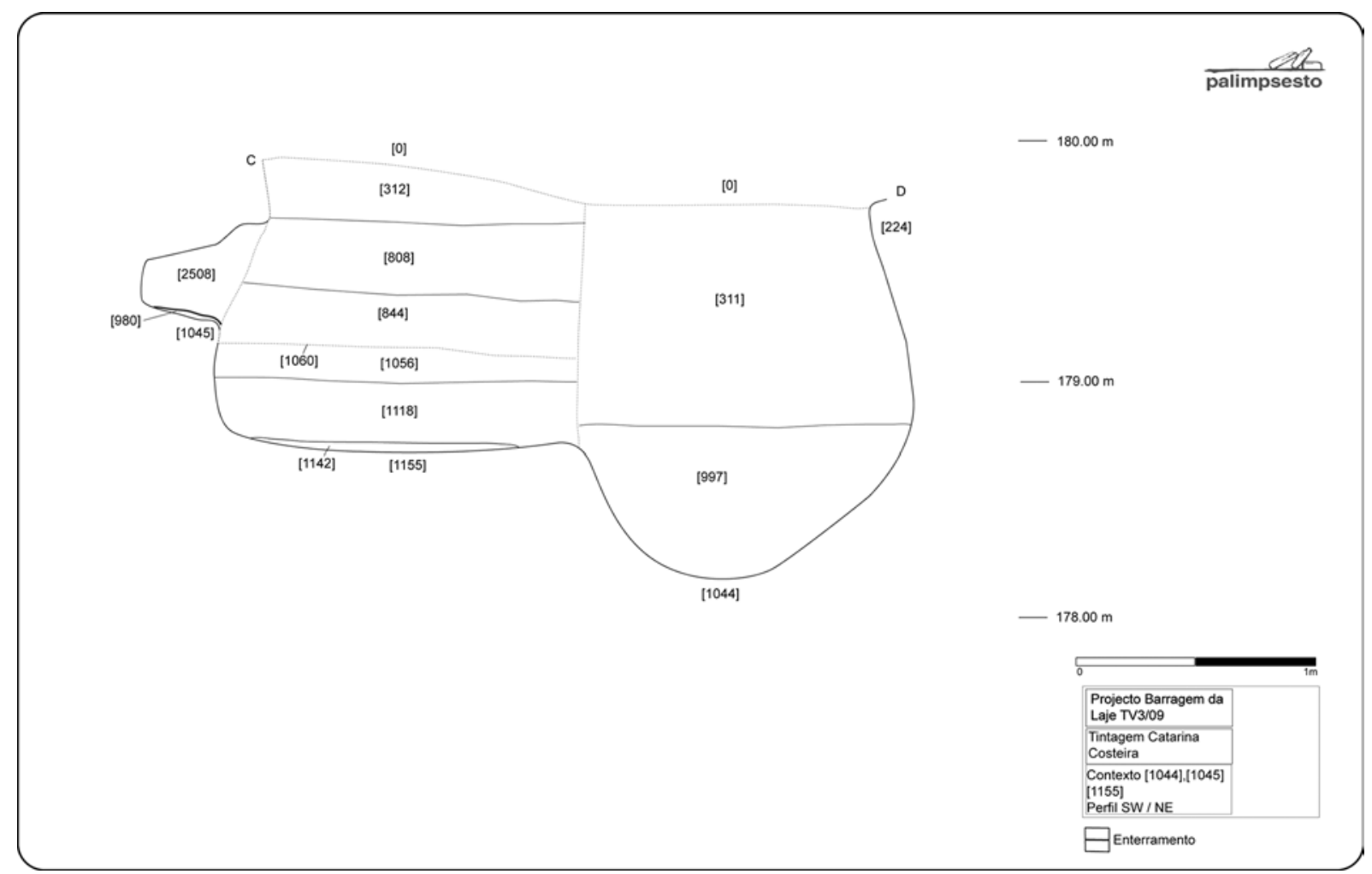

Fig. 7. Perfil SW-NE da estrutura [1155] e do nicho de enterramento [980].

Fig. 7. Section SW-NE from Pit [1155] and the burial [980] niche. 
ra, atendendo às diferenças altimétricas existentes na maioria dos casos, era realizada através de uma rampa ou de um escalonamento em degraus (Fig. 8). A condenação da câmara sepulcral era materializada através da deposição em cutelo de um ou vários blocos pétreos não aparelhados (Fig. 9). Para melhor colmatar e impermeabilizar o espaço deixado vago pelos elementos monolíticos, era por vezes aplicada uma argila muito rígida de grão grosseiro e coloração alaranjada (ALVES et al. no prelo a, b).

A utilização de argila para colmatar os espaços vazios e fortalecer ou substituir elementos da arquitectura pétrea, encontra paralelos em várias necrópoles de cistas do Bronze do Sudoeste, como é o caso de algumas sepulturas de Alfarrobeira (S. Bartolomeu de Messines), da Vinha do Casão (Vilamoura) e das cistas escavadas por Afonso do Paço e Joaquim Bação Leal no concelho de Mourão, nomeadamente na Herdade da Queijierinha e na Folha das Palmeiras (GOMEs et al. 1986; GOMES 1994; PAÇO \& LEAL 1962, 1962-63, 1963-64).

No entanto, os casos que julgamos apresentarem maiores semelhanças com os de Torre Velha 3, são aqueles onde a argila foi utilizada como elemento impermeabilizador pelas suas propriedades hidrófugas, como foi referenciado para um dos monumentos da Folha das Palmeiras (PAÇO \& LEAL 1962-63). Na cista do Montinho (Serpa) análises laboratoriais da autoria de Maria Isabel Ribeiro e de António Monge Soares comprovaram a utilização de uma gordura
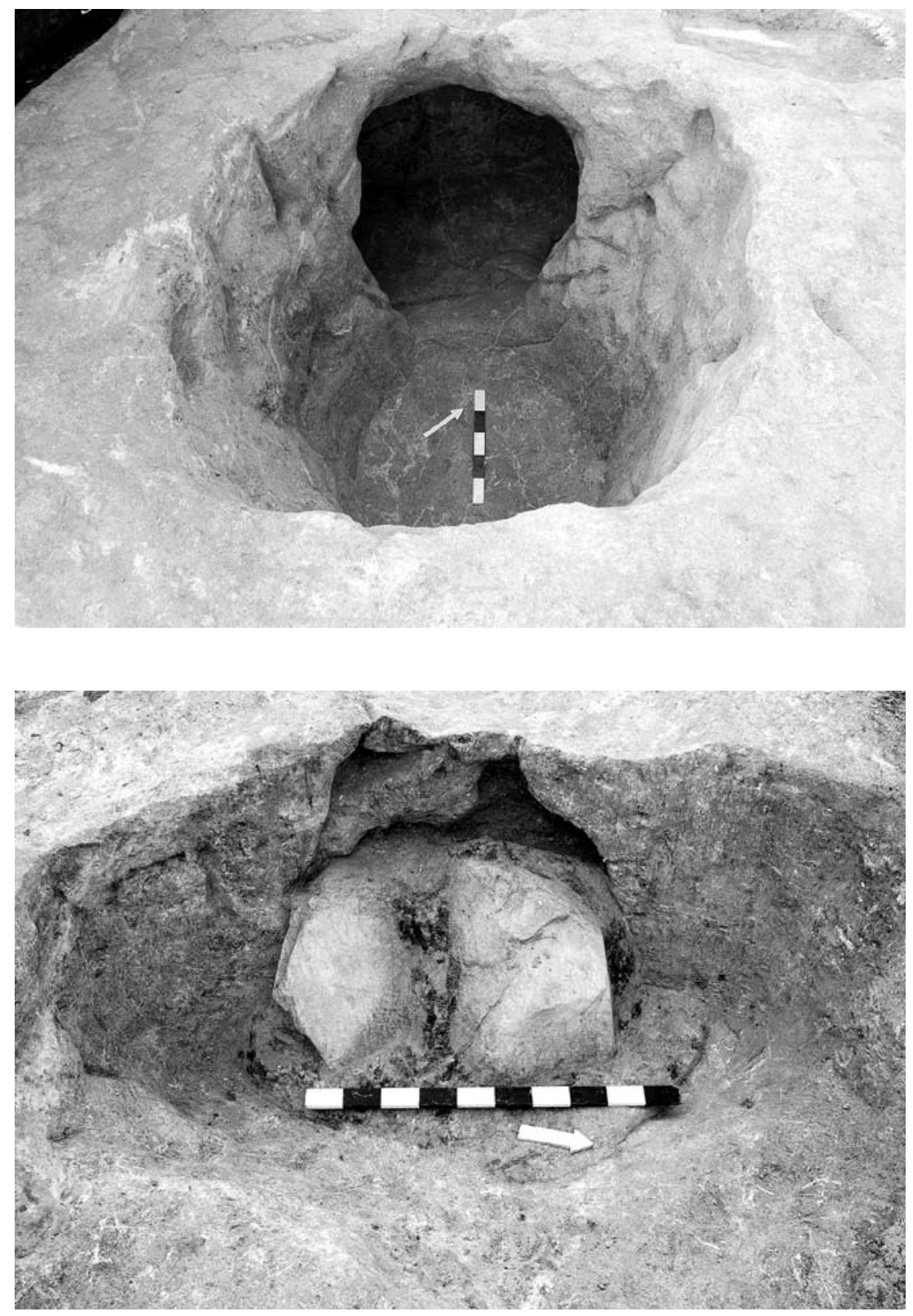

Fig. 8. Plano final do hipogeu [1662]-[1664].

Fig. 8. Hypogeum [1662]-[1664] after excavation.

Fig. 9. Blocos pétreos que selam a câmara do hipogeu [1298]$-[1665]$.

Fig. 9. Stone blocks sealing the hypogeum's chamber [1298]$-[1665]$. 
de origem animal para impermeabilizar a tampa da sepultura, não excluindo totalmente a hipótese de se tratar também de uma manifestação relacionada com o mundo simbólico (RIBEIRO \& SOARES 1991).

À diversidade patente na tipologia das estruturas funerárias da Idade do Bronze de Torre Velha 3 contrapõe-se uma certa homogeneidade ao nível dos rituais funerários. Assim, verifica-se que, ao nível da deposição do corpo, predomina a posição fetal, registando-se apenas duas excepções. Numa delas, constituída por uma deposição em decúbito dorsal num hipogeu, a justificação para o desvio em relação à norma deverá relacionar-se com as condições físicas do indivíduo que poderá ter impossibilitado a sua colocação em posição fetal (Fig. 10).
A segunda excepção é constituída pelos enterramentos [830] e [831], uma inumação dupla realizada numa fossa/silo com os indivíduos depositados em decúbito ventral. Foi propositadamente definida uma posição em que os crânios, através da colocação de vários blocos de pedra, ficaram voltados um para o outro e de modo a que os membros superiores de um dos indivíduos abraçasse o tronco do outro (Fig. 11). A singularidade destas inumações é reforçada pela ausência de algumas partes anatómicas, nomeadamente, a totalidade dos membros inferiores, da coluna e das vértebras, assim como, de um dos membros superiores de cada um dos indivíduos. O carácter preliminar do estudo antropológico não permite integrar, desde já, as especificidades desta deposição,
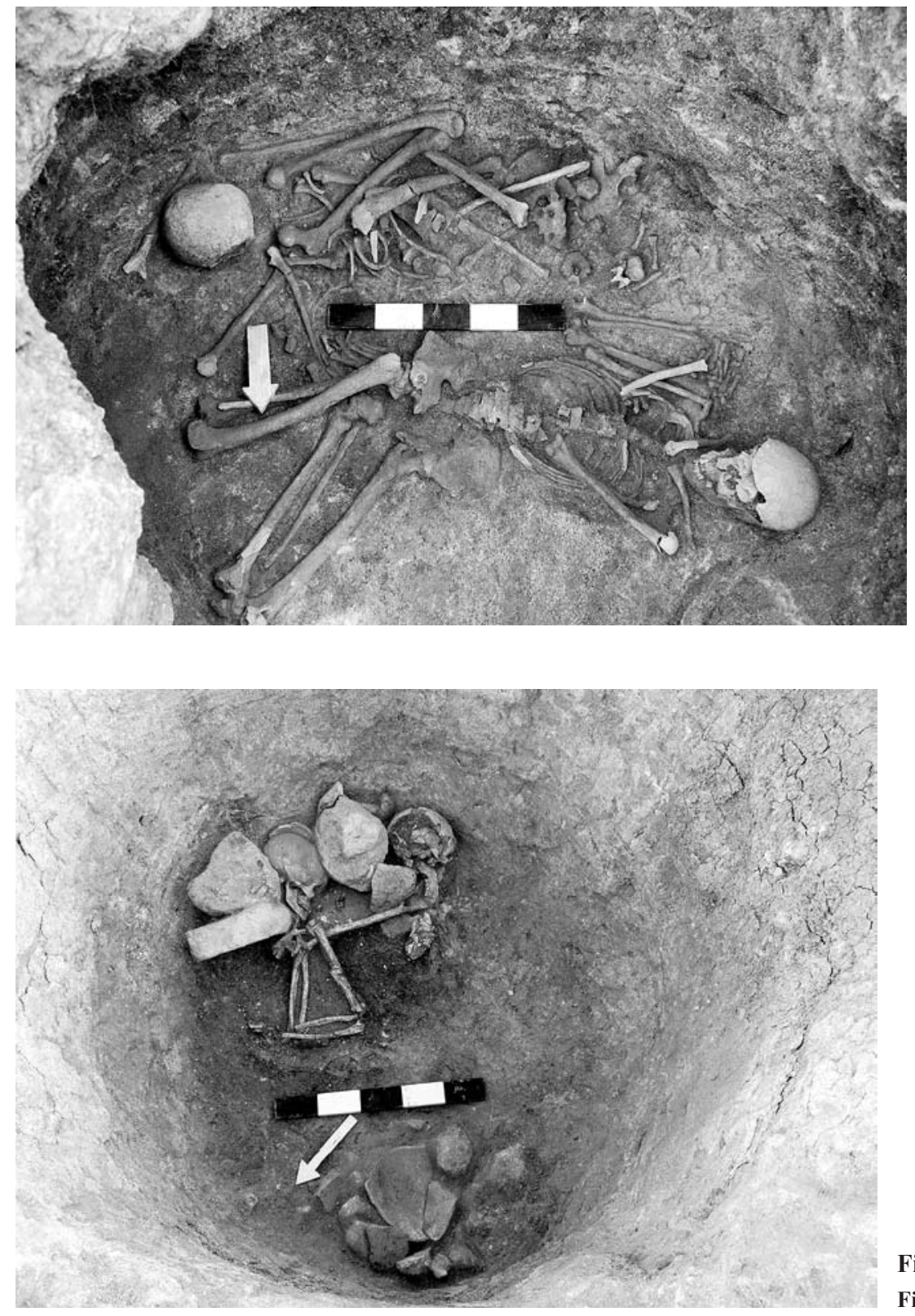

Fig. 10. Enterramento [2032].

Fig. 10. Burial [2032].
Fig. 11. Enterramentos [830]-[831].

Fig. 11. Burials [830]-[831]. 
no âmbito de uma actividade de desmembramento intencional do domínio do simbólico, que de algum modo, recorda a decapitação ritual da sepultura de Belmeque (SOARES 1994).

Referenciaram-se mais dois exemplos de inumações duplas, uma das quais, [2471]-[2472] conta ainda, para além dos dois indivíduos inumados, com duas reduções/ossários e vários ossos soltos. No hipogeu [1662]-[1664] realizou-se um enterramento acompanhado de redução e ainda o único caso identificado em toda a necrópole, de um enterramento realizado na antecâmara (ALVES et al. no prelo a, b).

As inumações duplas e os enterramentos associados a fenómenos de redução podem ser interpretados como indícios da existência de relações familiares entre os indivíduos que partilham o mesmo espaço sepulcral. Estes casos que, de algum modo, parecem transpor para o espaço funerário as relações sociais existentes no mundo dos vivos, fazem-nos repensar profundamente o sentido da expressão "enterramento individual". Decorrente destas situações, tem sido proposto para estas sociedades, uma estrutura social organizada em função dos quadros de valores da família alargada (CÁMARA SERRANO 2001; SILVA 1981), ou baseada na noção de parentesco estruturado em clãs ou famílias (AMO Y DE LA HERA 1993; GOMES 1994).

O modo como a organização social destas populações se materializaria nas manifestações funerárias pode vislumbrar-se na forma como algumas necrópoles de cistas se desenvolvem a partir de uma sepultura inicial, à qual se vão anexando outras, envolvidas por recintos pétreos de planta sub-circular, rectangular ou trapezoidal ou em grupos de tumuli adossados (GOMES 1994). Analisando a distribuição espacial dos hipogeus escavados em Torre Velha 3, verifica-se que, ao contrário da aleatoriedade da localização das fossas/silos com utilização funerária, estes, por seu turno, parecem agrupar-se em torno de duas áreas principais, se bem que desiguais ao nível do número e concentração de estruturas funerárias (cf. Fig. 4). Só a continuação do estudo deste sítio permitirá descortinar a existência de alguma significação subjacente a estes dois "núcleos" de hipogeus.

O espólio arqueológico associado aos enterramentos da Idade do Bronze encontra-se ainda numa fase muito preliminar do seu estudo, no entanto, é desde já possível verificar a existência de uma diferenciação entre os hipogeus e o grupo constituído pelas inumações em fossa/silo e em nicho. Neste último conjunto de estruturas constata-se que a grande maioria das inumações não possuem espólio associado, contando-se apenas três casos em que tal não acontece. Entre estes destaca-se o já mencionado caso do enterramento [830]-[831] que forneceu dois reci- pientes cerâmicos entre os quais uma taça carenada. Dos dois contextos restantes, provêem uma oferenda cárnea e duas lâminas de sílex incompletas.

Os materiais arqueológicos recolhidos nos hipogeus apresentam uma maior diversidade associando à cerâmica, as oferendas cárneas, os elementos metálicos e de adorno. Entre as peças cerâmicas é de referir a presença de formas típicas deste período cultural como as garrafas, os vasos de nervuras verticais, as taças de tipo Atalaia, Santa Vitória e Odivelas. Estas tipologias remetem-nos, de imediato, para os conjuntos cerâmicos presentes nas cistas do Bronze do Sudoeste, especialmente daquelas localizadas na margem esquerda do Guadiana, integrando desde logo Torre Velha 3 neste âmbito cultural (ALVES et al. 2010).

Por outro lado, destaca-se uma taça de pé que é, até este momento, um tipo desconhecido nos reportórios cerâmicos do Bronze do Sudoeste (Fig. 12). As semelhanças morfológicas desta peça com a forma 7 de Siret (SCHUBART 2004), permite supor a existência de algum tipo de relações com as comunidades contemporâneas do Sudeste peninsular. Um vaso bicónico, cuja forma se aproxima de um recipiente recolhido na necrópole de Santa Justa em Serpa (SOARES 1994), mas cujos paralelos mais directos poderão ser procurados na forma 6 de Siret, será outro elemento adicional a indiciar contactos com o Sudeste da Península (Fig. 13).

O punção, com 11 exemplares, é o elemento metálico mais representado nos espólios funerários, seguido das facas e punhais em muito menor número, com 4 presenças. Os objectos de adorno são constituídos por um anel em forma de espiral e secção circular, um colar composto por quatro pares de contas manufacturadas a partir de material conquífero, osteológico e metálico (liga de cobre e prata com duas contas cada) e um outro constituído por 31 búzios. Excluindo as matérias-primas dos dois colares já descritos, todos os outros objectos de metal foram produzidos numa liga de cobre.

Documentou-se, para 10 casos, a existência de restos osteológicos de animais, alguns dos quais em conexão anatómica, como parte integrante do espólio e do ritual funerário (Fig. 14). A análise destes restos ósseos pela Dr. ${ }^{a}$ Marta Moreno García, do Instituto de Historia do CSIC (a quem agradecemos desde já este inestimável contributo) permitiu constatar a existência de um padrão materializado na preferência pela parte distal do membro inferior dianteiro dos animais e na presença esmagadora, excluindo um único caso de ovino, de ossos de bovino, ambos pertencentes a espécies domésticas. Reforçando a existência de um ritual estandardizado, verificou-se ainda que associados a cada enterramento humano 


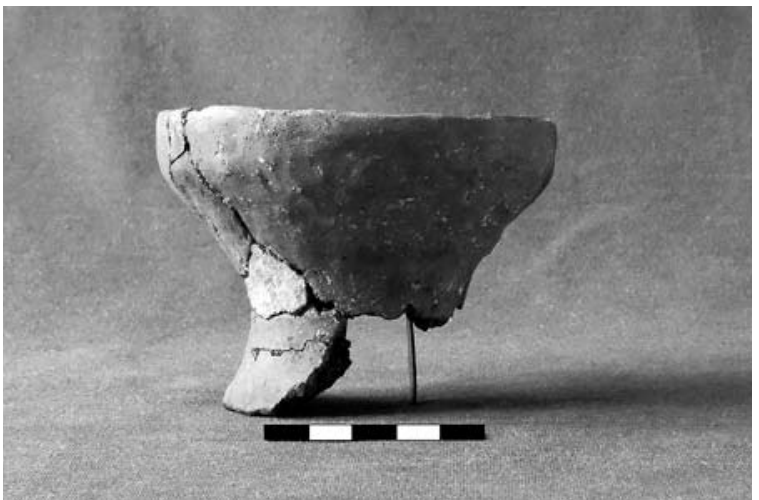

Fig. 12. Taça de pé n. ${ }^{\circ} 3445$.

Fig. 12. Grave good, cup n. ${ }^{\circ} 3445$.

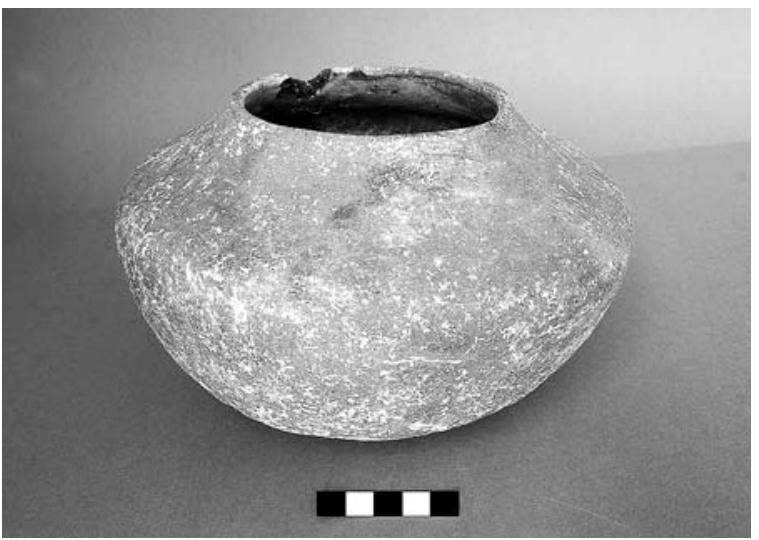

Fig. 13. Vaso bicónico n. ${ }^{\circ} 3654$.

Fig. 13. Grave good, vessel n. ${ }^{\circ} 3654$. eram apenas depositados os ossos da pata esquerda de um único animal.

O mau estado de conservação dos restos faunísticos condicionou em grande medida a qualidade da análise, impossibilitando a recolha de dados osteométricos e o reconhecimento das marcas associadas ao processamento da carne (ALVES 2010).

Os restos osteológicos de animais identificados em alguns contextos funerários de Torre Velha 3, à semelhança dos existentes em Belmeque (Soares 1994) e Outeiro Alto 2 (VAlerA \& Filipe 2010), demonstram que a prática da comensalidade era parte integrante do cerimonial fúnebre dos indivíduos inumados nos hipogeus.

\section{CONSIDERAÇÕES FINAIS}

A análise realizada aos contextos funerários da Idade do Bronze de Torre Velha 3 tem ainda um carácter preliminar, devido essencialmente ao estado inicial dos estudos dos materiais arqueológicos. Este facto reveste-se de uma importância capital dada a inexistência de relações estratigráficas directas entre as várias estruturas, assim como a impossibilidade de as datar todas através de métodos absolutos, faz recair sobre o estudo de materiais a responsabilidade de contribuir para a compreensão da dinâmica ocupacional deste sítio arqueológico.

No entanto, é desde já possível estabelecer uma série de considerações, umas de carácter mais defi-

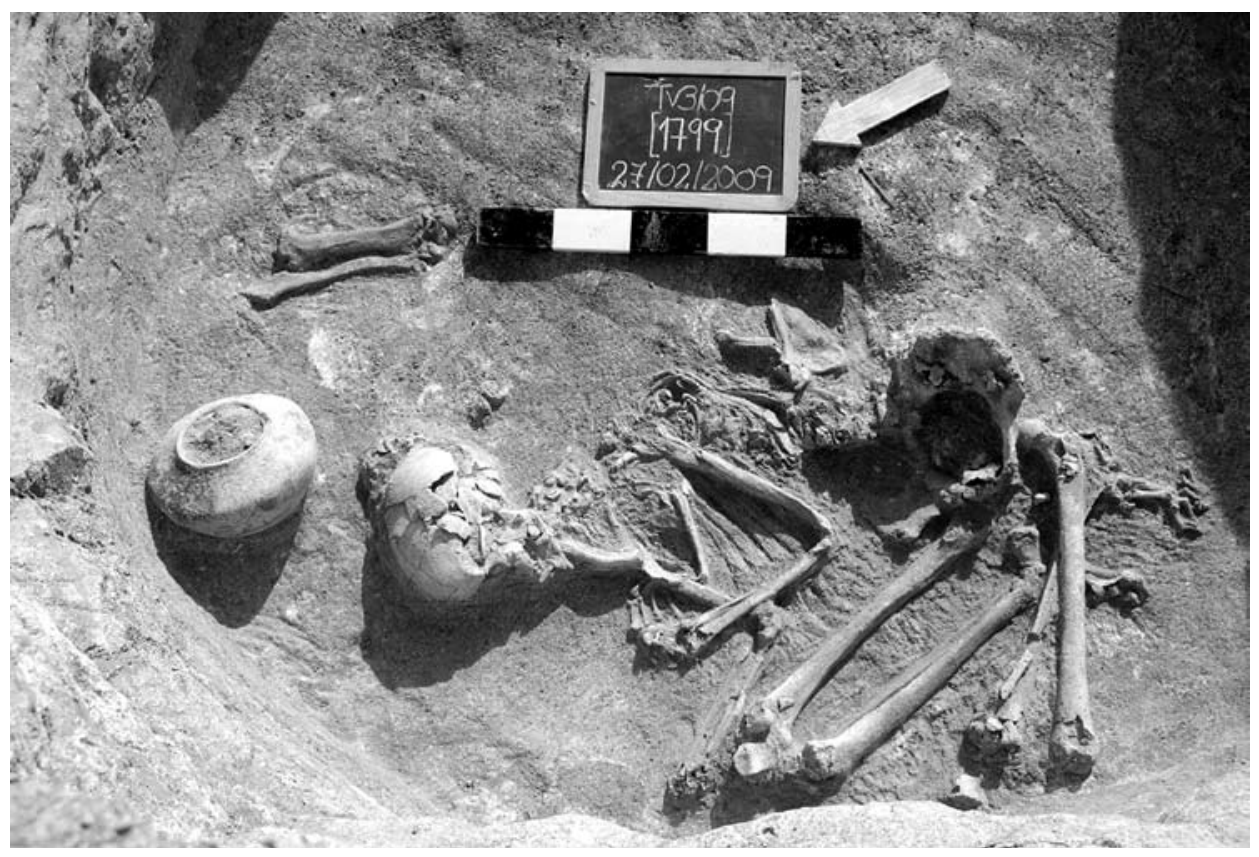

Fig. 14. Enterramento [1799] com oferenda cárnea em conexão anatómica.

Fig. 14. Grave good's from Burial [1799], including animal bones in anatomical connection. 
nitivo, outras de feição preliminar, que se constituem em hipóteses e perspectivas de investigação a desenvolver posteriormente.

Entre as ilações do primeiro tipo encontram-se aquelas relativas à caracterização do ritual funerário, principalmente no que se refere à preferência pela posição fetal para a realização dos enterramentos, quer nos silos/fossas, incluindo o caso em cuja parede foi escavado um nicho, quer nos hipogeus.

No que se refere ao espólio, verificou-se uma diferença quantitativa favorável aos enterramentos em hipogeu e desfavorável ás inumações em silos/ /fossas. De momento, dada a inexistência de datações absolutas para os enterramentos do segundo tipo, não é possível apreender a real significação desta diferença. Corresponderá a uma diferença cronológica ou, por outro lado, materializará post mortem o estatuto inferior do indivíduo no interior destas sociedades?

Outro elemento que é necessário considerar nesta discussão prende-se com a presença de oferendas cárneas entre o espólio depositado nos hipogeus, com excepção de um único caso em silo/fossa. A realização de actos de comensalidade envolvendo o sacrifício e o consumo de animais, aquando das exéquias de um membro do grupo, implicariam a participação de toda ou de parte da comunidade num momento importante para reafirmar o sentido de comunidade? $\mathrm{Na}$ área argárica, o cruzamento entre os dados antropológicos dos inumados e as características do espólio e dos restos faunísticos permitiram concluir que os actos de comensalidade, realizados durante o ritual funerário, desempenhavam um papel importante para a exibição de riqueza e consequentemente para a manutenção da hierarquização social, materializada num acesso diferenciado aos bens de produção (ARANDA JIMÉNEZ \& ESQUívEL GUERRERO 2006).

Para o caso de Torre Velha 3 o estado preliminar dos estudos não permitem observações tão categóricas como as que foram obtidas para o mundo argárico, nomeadamente aquelas relativas quer à composição diferenciada do espólio consoante o sexo do inumado, quer à associação de certas espécies animais como os bovinos e ovinos aos estratos sociais mais elevados da sociedade (ARANDA JIMÉNEZ \& ESQUívEL GUERRERO 2006). Em Torre Velha 3 verificou-se, apesar de tudo, a existência de uma correlação entre as oferendas de bovino e os indivíduos de idade adulta, tanto mais que o único resto de ovino foi depositado junto a um indivíduo muito mais jovem (ALVES et al. 2010).

Um conhecimento mais aprofundado das questões inerentes aos ritos de comensalidade no sítio Torre Velha 3 só será possível através da concretização de um programa de estudos interdisciplinar que se debruce sobre os diversos elementos recolhidos no decorrer da intervenção de campo. Entre estes, há que incluir obrigatoriamente um aprofundamento das análises faunísticas já realizadas.

Não deverão também, ser descartadas as informações obtidas a partir dos micro-restos que ainda poderão subsistir nas paredes dos recipientes cerâmicos, bem como das que poderão ser obtidas a partir das análises aos vários sedimentos recolhidos nos contextos funerários. Poderá, deste modo, averiguar-se qual a dimensão desempenhada pelos elementos vegetais nos actos de comensalidade funerária.

Neste momento, não é ainda clara a natureza da relação entre as estruturas com utilização funerária e as restantes, cujos enchimentos fornecem poucos ou nenhuns dados sobre os seus momentos de actividade, documentando apenas o momento da sua colmatação final.

Serão estas estruturas o único elemento sobrevivente do local de habitação da comunidade que sepultou nos silos/fossas e nos hipogeus?

O pouco, que conhecemos sobre os povoados associados às necrópoles de cistas do Bronze do Sudoeste, parecem indicar que se situavam nas proximidades ou a poucos metros dos lugares destinados às sepulturas.

Pode-se colocar, com muita pertinência, a possibilidade de em Torre Velha 3, vivos e mortos terem compartilhado o mesmo espaço físico, quer em situação de sobreposição, quer de vizinhança. Deste modo, os papéis sociais de uns e de outros intersectar-se-iam no dia-a-dia (SOARES et al. 2009), não sendo de todo descabido argumentar que os mortos continuariam de algum modo presentes na vida quotidiana.

Esta presença poderia efectivar-se através da circulação de ossos entre os vivos (BRÜCK 1995), mesmo se tal não acontecesse, a reabertura amiúde de sepulturas para a realização de novas inumações colocaria frequentemente em contacto mortos e vivos, contribuindo para esbater as diferenças entre aquelas dimensões da existência.

Neste sentido pode atentar-se na frase de Mike Parker Pearson "The passage from life into death and beyond may not have been the abrupt transition between two states - alive and dead - that we often consider it to be. Death was not in opposition to life but a stage in the continuation of existence" (PEARSON 1999: 161).

A prática da comensalidade no decurso dos rituais funerários seria assim, um momento congregador da comunidade, reunindo vivos e mortos. Constituiria a materialização de um elo que pontuaria a vida quotidiana destas populações, cuja materialização poderá ser encontrada na proximidade que parece existir, no Bronze do Sudoeste, entre povoado e necrópole. 


\section{AGRADECIMENTO}

Os autores agradecem ao Eng. Monge Soares as informações preliminares relativas à composição dos elementos metálicos. Agradecem, também, a Ana M. $\mathrm{S}$. Bettencourt a leitura inicial do texto e as sugestões que melhoraram a qualidade deste trabalho, salvaguardando no entanto que eventuais erros e omissões são da total responsabilidade dos autores.

\section{BIBLIOGRAFIA}

Almagro GorbeA, M. 1977. El Bronce Final y el periodo orientalizante en Extremadura. Biblioteca Praehistorica Hispana 14. Madrid.

Alves, C.; Costeira, C.; Estrela, S.; Porfírio, E. \& Serra, M. no prelo a. Torre Velha 3 (Serpa): dados preliminares, Al-madan 17. 2. ${ }^{\mathrm{a}}$ série.

Alves, C.; Costeira, C.; Estrela, S.; Porfírio, E. \& Serra, M. no prelo b. Caracterização preliminar da ocupação pré-histórica da Torre Velha 3 (Barragem da Laje - Serpa). $44^{\circ}$ Colóquio de Arqueologia do Alqueva - O plano de rega (2002-2010). EDIA.

Alves, C.; Costeira, C.; Estrela, S.; Porfírio, E; Serra, M.; SoAres, A.M. \& Moreno Garcia, M. 2010. Hipogeus funerários do Bronze Pleno da Torre Velha 3 (Serpa, Portugal). Zephyrus 66: 133-153.

AMO y DE LA HeRA, M. 1993. Formas e ritos funerários en las necrópolis de cistas del suroeste peninsular. SPAL 1: 169-182.

ARANDA JiMÉNEZ, G. 2008. Introducción: Somos lo que comemos. El significado social del consumo de alimentos y bebidas. Revista de Prehistoria y Arqueologia de la Universidad de Granada 18: 11-16.

ARANDA JimÉnEZ, G. 2008a. Cohesión y distancia social. El consumo comensal de bóvidos en el ritual funerário de las sociedades argáricas. Revista de Prehistoria y Arqueologia de la Universidad de Granada 18: 107-123.

Aranda JimÉnEZ, G. \& Esquivel Guerrero, J.A. 2006. Ritual funerario y comensalidad en las sociedades de la Edad del Bronce del Sureste peninsular: la Cultura de El Argar. Trabajos de Prehistoria 63 (2): 117-133.

Aranda Jiménez, G. \& Esquivel Guerrero, J.A. 2007. Poder y prestigio en las sociedades de la cultura de El Argar. El consumo comunal de bóvidos y ovicápridos en los rituales de enterramiento. Trabajos de Prehistoria 64 (2): 95-118.

BARCELO, J.A. 1991. El Bronce del Sudoeste y la cronologia de las estelas alentejanas. Arqueologia 21: 15-24.

BRÜCK, J. 1995. A place for the dead: the role of human remains in Late Bronze Age Britain. Proceedings of the Prehistoric Society 61: 245-277.

CÁMARA SERRANO, J.A. 2001. El ritual funerario en la prehistoria reciente en el sur de la Peninsula Ibérica. BAR International Series 913. Oxford. Archaeopress.

CAstro, P.V.; Chapman, R.W.; Gili Suriñach, S.; Lull, V.; Micó Pérez, R.; Rihuete Herrada, C.; Risch, R.; \& SANAHUJA YLL, M.E. 2001. La sociedad argárica. In M. Ruiz-Gálvez Priego (ed.) La edad del bronce, primera edad de oro de España? Madrid: Editorial Crítica: 181-216.

COnTreras CORTÉs, F.; Rodriguez, M.O.; CÁMARA SERrano, J.A. \& Moreno, A. 1997. Hace 4000 años. Vida y muerte en dos poblados de la Alta Andalucía. Granada: Junta de Andalucía.

DIETLER, M. 1996. Feasts and commensal politics in the political economy. Food power and status in Prehistoric Europe. In P. Wiessner \& W. Schiefenhövel (ed.) Food and the status quest. An interdisciplinary perspective. Providence/Oxford: Berghahn Books: 87-125.

DiETLER, M. 2001. Theorizing the feast: ritual of consumption, commensal politics, and power in African contexts. In $\mathrm{M}$. Dietler \& B. Hayden (ed.) Feasts archaeological and ethnographic perspectives on food, politics, and power. Washington and London: Smithsonian Institution Press: 65-114.

Dietler, M. \& Hayden, B. 2001. Feasts archaeological and ethnographic perspectives on food, politics, and power. Washington and London, Smithsonian Institution Press.

FERNANDES, A.T. 1997. Ritualização da Comensalidade. Revista da Faculdade de Letras do Porto: Sociologia 7: 7-30.

FEIO, M. 1952. A evolução do relevo do Baixo Alentejo e Algarve. Estudos de Geomorfologia. Lisboa: Instituto para a Alta Cultura - Centro de Estudos Geográficos.

Formosinho, J.; Ferreira, O.V. \& VianA, A. 1953-54. Estudos arqueológicos nas Caldas de Monchique. Trabalhos de Arqueologia e Etnologia 14 (1-4): 66-225.

Gomes, M.V. 1994. A necrópole de Alfarrobeira (S. Bartolomeu de Messines) e a Idade do Bronze no concelho de Silves. Xelb 2. Silves: Museu Municipal de Arqueologia e Câmara Municipal de Silves.

Gomes, M.V.; Gomes, R.V.; BeIrÃo, C. Mello \& Matos, J.L. 1986. A necrópole da Vinha do Casão (Vilamoura, Algarve) no contexto da Idade do Bronze do Sudoeste Peninsular. Trabalhos de Arqueologia 2. Lisboa: Instituto Português do Património Cultural.

Gomes, M.V. \& MonteIRo, J.P. 1976-1977. As estelas decoradas da Herdade do Pomar (Ervidel - Beja) - Estudo comparado. Setúbal Arqueológica 2-3: 281-344.

Gomes, M.V. \& MonTeiro, J.P. 1977. Las estelas decoradas do Pomar (Beja-Portugal). Estudio comparado. Trabajos de Prehistoria 34: 165-214.

HAYDEN, B. 1996. Feasting in the Prehistoric and traditional societies. In P. Wiessner \& W. Schiefenhövel (ed.) Food and the status quest. An interdisciplinary perspective Oxford: Berghahn Books: 127-147.

HAYDEN, B. 2001. Fabulous feasts: a prolegomenon to the importance of feasting. In M. DIETLER \& B. HAYDEN (ed.) Feasts archaeological and ethnographic perspectives on food, politics, and power. Washington and London: Smithsonian Institution Press: 23-64.

JimÉNEZ DíEZ, J.A. 2002. Historiografia de la Pre e Protohistoria de la Península Ibérica en el siglo XIX. Madrid: Faculdade de Geografia e História da Universidade Complutense de Madrid. Dissertação de doutoramento (policopida).

Mederos Martín, A. 2009. La sepultura de Belmeque (Beja, Bajo Alentejo). Contactos con el Egeo durante el Bronce Final I del Suroeste de la Península Ibérica (1625-1425 AC). Veleia 26: $235-264$.

Milner, N. \& Miracle, P. 2002. Consuming passions and patterns of consumption. McDonald Institute Monographs. Cambridge: McDonald Institute for Archaeological Research, University of Cambridge.

OliveIRA, J.T. (coord.) 1992. Carta Geológica de Portugal-escala 1:200 000, Notícia explicativa da folha 8. Lisboa: Serviços Geológicos de Portugal. 
PAÇO, A. \& LEAL, J.B. 1962. Sepulturas argáricas da "Folha das Palmeiras" (Mourão). Actas do XXVI Congresso Luso- Espanhol da Associação Portuguesa para o Progresso das Ciências. Secção VII. Porto: 339-345.

PAÇO, A. \& LEAL, J.B. 1962-63. Sepulturas argáricas da Folha das Palmeiras. A Cidade de Évora 45/46: 21-24.

PAÇO, A. \& LEAL, J.B. 1963-64. Sepulturas argáricas da Herdade da Queijeirinha (Mourão). Arquivo de Beja 20/21: 69-72.

PARreirA, R. 1995. Aspectos da Idade do Bronze no Alentejo Interior. A Idade do Bronze em Portugal-discursos de poder. Lisboa: Secretaria de Estado da Cultura, Instituto Português de Museus: 131-135.

PAVÓn SoldeVILla, I. 2008. El mundo funerario de la Edad del Bronce en la Tierra de Barros: una aproximación desde la bio-arqueología de Las Minitas. Memorias de Arqueología Extremeña 9. Mérida.

PEARSON, M.P. 1999. The Archaeology of Death and Burial. Sutton Publishing Ltd.

Ribeiro, M.I. \& SoARES, A.M. 1991. A sepultura do Bronze do Sudoeste da Herdade do Montinho (Vale do Vargo, Serpa). Aplicação de alguns métodos instrumentais de análise química a um problema arqueológico. Actas das IV Jornadas Arqueológicas (Lisboa-1990). Lisboa: Associação dos Arqueólogos Portugueses: 287-298.

RUIZ-GÁLVEZ, M. 1984. Reflexiones terminológicas en torno a la edad del bronce peninsular peninsular. Trabajos de Prehistoria 41: $323-342$

SÁNCHEZ ROMERO, M. 2008. El consumo de alimento como estrategia social: recetas para la construcción de la memoria y la creación de identidades. Revista de Prehistoria y Arqueologia de la Universidad de Granada 18: 17-39.

SÁNCHEZ RoMERo, M.; ARANDA JimÉNEZ, G.; \& ALARCÓN GARCÍA, E. 2007. Gender age identities in rituals of comensality. The argaric societies. Treballs d'Arqueologia 13: 69-89.

SÁRdA SEUmA, S. 2010. El giro comensal: nuevos temas y nuevos enfoques en la Protohistoria Peninsular. Herakleion 3: 37-65.

Schubart, H. 1971. O Horizonte de Ferradeira. Sepulturas do Eneolítico Final no Sudoeste da Península Ibérica. Revista de Guimarães 81: 189-215.
SchubarT, H. 1971a. Acerca de la ceramica del Bronce Tardio en el Sur y Oeste Peninsular. Trabajos de Prehistoria 28: 153-182.

SCHUBART, H. 1974. Novos achados sepulcrais do Bronze do Sudoeste II. Actas das II Jornadas Arqueológicas. Vol. II. Lisboa: Associação dos Arqueólogos Portugueses: 65-86.

SCHUBART, H. 1975. Die Kultur der Bronzezeit in Südwesten der Iberischen Halbinsel, Berlim:Walter de Gruyter \& Co.

SCHUBART, H. 2004. La cerámica argárica en la estratigrafia de Fuente Álamo. Campañas de 1977-1982, SPAL 13: 35-82.

Silva, C.T. \& Soares J. 1981. Pré-história da área de Sines. Trabalhos arqueológicos de 1972-77. Lisboa: Gabinete da Área de Sines.

Silva, C.T. \& SoARes J. 1995. O Alentejo Litoral no contexto da Idade do Bronze do Sudoeste Peninsular. A Idade do Bronze em Portugal - discursos de poder. Lisboa: Secretaria de Estado da Cultura, Instituto Português de Museus: 136-139.

Silva, C.T. \& SoARES J. 1998. From the collapse of the calcolithic mode of production to the development of the Bronze Age societies in the south-west of Iberian Peninsula. In S.O. JORGE (ed.) Existe uma Idade do Bronze Atlâtico? Trabalhos de Arqueologia 10. Lisboa: IPA: 231-245.

SoARES, A.M. 1994. O Bronze do Sudoeste na margem esquerda do Guadiana. As necrópoles do concelho de Serpa. Actas das V Jornadas Arqueológicas (Lisboa-1993). Lisboa: Associação dos Arqueólogos Portugueses: 179-197.

Soares, A.M. \& Santos, F.; Dewulf, J.; Deus, M.; Antunes, A.S. 2009. Práticas rituais no Bronze do Sudoeste - alguns dados. Estudos Arqueológicos de Oeiras 17: 433-456.

VAlerA, A.C. \& Filipe, V. 2010. Outeiro Alto 2 (Brinches, Serpa): Nota preliminar sobre um espaço funerário e de socialização do Neolítico à Idade do Bronze. Apontamentos de Arqueologia e Património 5: 49-56.

VeIgA, S.P.M.E. 2005. Paleoetnologia - Antiguidades Monumentaes do Algarve - Tempos pré-históricos. Vol. 4. Faro: Universidade do Algarve.

WIESSNER, P. \& SCHIEFENHÖVEL, W. 1996. Food and the status quest. An interdisciplinary perspective. Oxford: Berghahn Books. 